\title{
Substrate utilization by endophytic bacteria Paenibacillus polymyxa P2b-2R that may facilitate bacterial entrance and survival inside diverse plant hosts
}

\author{
Henry Yang ${ }^{\mathrm{a}}$, Akshit Puri ${ }^{\mathrm{a} \star}$, Kiran Preet Padda ${ }^{\mathrm{a}}$, and Chris P. Chanway \\ ${ }^{\mathrm{a}}$ Department of Forest and Conservation Sciences, University of British Columbia, Forest Sciences Centre \\ 3041, 2424 Main Mall, Vancouver, BC V6T 1Z4, Canada \\ *akshit.puri@alumni.ubc.ca
}

\begin{abstract}
Bacterial endophytes are thought to enter plants either through pre-existing openings in plant tissues or by creating openings by hydrolyzing major plant cell wall components. A lodgepole endophyte, Paenibacillus polymyxa P2b-2R, consistently formed endophytic colonies when inoculated in diverse plant hosts, viz., lodgepole pine, western red cedar, corn, canola, and tomato. We were interested to know, whether or not this bacterial strain possesses enzymes that can hydrolyze three major plant cell wall components namely cellulose, xylan, and pectin to facilitate entrance into the host plants. Using a BIOLOG assay, we also tested this bacterial strain's ability to utilize carbon sources that might facilitate its entrance and hence its survival inside host plants. Paenibacillus polymyxa P2b-2R hydrolyzed sodium carboxymethylcellulose, beechwood xylan, and sodium polypectate and utilized 39 of the 95 carbon sources (41\%) tested. Of the 39 carbon substrates oxidized by P2b-2R, the "carbohydrates" group represents the largest source of utilizable carbon (23 out of 39). Thus, it can be concluded that P. polymyxa $\mathrm{P} 2 \mathrm{~b}-2 \mathrm{R}$ is able to degrade major cell wall components (cellulose, xylan, and pectin) and utilize some of the available carbon substrates, possibly to gain entry and survive inside the plant and form endophytic colonies thereafter.
\end{abstract}

Chanway CP. 2017. Substrate utilization by endophytic bacteria Paenibacillus polymyxa P2b-2R that may facilitate bacterial entrance and survival inside diverse plant hosts. FACETS 2: 120-130. doi: 10.1 139/ facets-20 | 6-003 |

Editor: Elena P. Ivanova

Received: July 9, 2016

Accepted: November 15, 2016

Published: February 9, 2017

Copyright: (c) 2017 Yang et al. This work is licensed under a Creative Commons Attribution 4.0 International License (CC BY 4.0), which permits unrestricted use, distribution, and reproduction in any medium, provided the original author(s) and source are credited.

Published by: Canadian Science Publishing

Key words: endophyte, Paenibacillus polymyxa, colonization, carbon substrate, plant cell wall degradation

\section{Introduction}

The term "bacterial endophyte" is used to describe a bacterium that colonizes internal plant tissues without inducing disease symptoms (Hallmann et al. 1997; Azevedo et al. 2000). Endophytic bacteria are thought to enter plants through pre-existing openings such as emergence sites of lateral roots or wounds to external plant tissues (James et al. 1994). Alternatively, it is possible that bacterial endophytes may create openings by hydrolyzing major plant cell wall components such as cellulose, hemicellulose, or pectin (Compant et al. 2005; Reinhold-Hurek et al. 2006). The ability of bacterial endophytes to evade plant defenses is thought to involve the production of enzymes that degrade elicitors of plant immune responses (Fouts et al. 2008) and to be essential for successful endophytic colonization (Bulgarelli et al. 2013). By occupying the plant interior, bacterial endophytes may have a comparative advantage over rhizosphere-colonizing bacteria due to ready access to continuous 
supplies of nutrients and an additional degree of protection from competition and predation that likely occur outside plant roots (Hallmann et al. 1997). Certain bacterial endophytes may, in turn, enhance the fitness of their plant hosts by inducing systemic defense (Kavino et al. 2007) or providing essential growth-limiting compounds such as nitrogen (N; Dong et al. 1994). Gluconacetobacter diazotrophicus was found to possess cellulolytic enzymes (Mateos et al. 1992; Adriano-Anaya et al. 2005 ) and was able to grow on media supplemented with $10 \%$ sucrose and tolerate low $\mathrm{pH}$ (Boddey et al. 1991). These characteristics were thought to facilitate endophytic colonization of sugarcane tissues by G. diazotrophicus, which was confirmed in studies where it reached high population densities (Döbereiner et al. 1988; Munoz-Rojas and Caballero-Mellado 2003).

Paenibacillus polymyxa is an endospore-forming, non-pathogenic bacterium readily found in environments such as plant roots, soil, and marine sediments (Timmusk et al. 2005; Ravi et al. 2007). Bal et al. (2012) successfully isolated several Paenibacillus strains that possess significant acetylene-reduction activity ( $\mathrm{N}$-fixing capacity) from the extracts of surface-sterilized lodgepole pine seedling and tree tissues. When one of the strains, P. polymyxa P2b-2R, was re-inoculated in lodgepole pine and grown in an N-limited soil for 13 months, the bacterial strain successfully colonized internal stem and root tissues of lodgepole pine seedlings, fixed a significant amount of $\mathrm{N}$ from the atmosphere (79\%), and promoted the overall growth of seedlings (Anand et al. 2013; Yang et al. 2016). Furthermore, a green fluorescent protein-labeled derivative of $\mathrm{P} 2 \mathrm{~b}-2 \mathrm{R}$ was shown to colonize internal tissues of lodgepole pine seedlings (Anand and Chanway 2013a). The ability of P. polymyxa P2b-2R to promote growth and to consistently form endophytic colonies inside a broad range of hosts was also confirmed in western red cedar (Anand and Chanway 2013b), corn (Puri et al. 2015, 2016b), canola (Padda et al. 2016b; Puri et al. 2016a), and tomato (Padda et al. 2016a). However, the question arises, how does $P$. polymyxa P2b-2R enter the host plant to form endophytic micro-colonies? In this study, we tested the working hypothesis that $P$. polymyxa $\mathrm{P} 2 \mathrm{~b}-2 \mathrm{R}$ possesses enzymes that can hydrolyze major plant cell wall components, like carboxymethylcellulose (CMC), xylan, and sodium polypectate, which then facilitates its entrance into the host plant.

\section{Materials and methods}

Paenibacillus polymyxa strain P2b was isolated from surface-sterilized stem tissue of a lodgepole pine seedling that was naturally regenerating near Williams Lake, British Columbia, Canada (latitude: $52^{\circ} 05^{\prime \prime} \mathrm{N}$; longitude: $122^{\circ} 54^{\prime \prime} \mathrm{W}$; elevation: $1300 \mathrm{~m}$; Sub-Boreal Pine Spruce (SBPSdc) Zone; Bal et al. 2012). Paenibacillus polymyxa P2b-2R is a spontaneous antibiotic-resistant mutant that was derived from strain $\mathrm{P} 2 \mathrm{~b}$ (Bal et al. 2012). Paenibacillus polymyxa $\mathrm{P} 2 \mathrm{~b}-2 \mathrm{R}$ is resistant to $200 \mathrm{mg} / \mathrm{L}$ rifamycin and was stored at $-80^{\circ} \mathrm{C}$ on combined carbon medium (CCM; Rennie 1981) amended with $20 \%$ glycerol (Bal et al. 2012). To evaluate the ability of P2b-2R to degrade plant cell wall components, $50 \mu \mathrm{L}$ of P2b-2R $\left(\sim 10^{7} \mathrm{cfu} / \mathrm{mL}\right)$ was spot-inoculated on Luria-Bertani (LB) agar amended with one of the following substrates $(5 \mathrm{~g} / \mathrm{L})$ : sodium CMC, beechwood xylan, or sodium polypectate, and incubated for two days at $30^{\circ} \mathrm{C}$. To visualize substrate utilization, plates with sodium CMC or xylan were flooded with $0.5 \%(w / v)$ Congo red for $30 \mathrm{~min}$, drained, and then rinsed with $1 \mathrm{~mol} / \mathrm{L} \mathrm{NaCl}$ (Cho et al. 2007). To visualize pectate lyase activity, sodium polypectate plates were flooded with $10 \%(w / v)$ copper acetate for $30 \mathrm{~min}$, drained, and rinsed with distilled water (Cho et al. 2007). Clear zones around the bacterial colonies on plates indicated enzyme activity. Carbon substrate utilization of strain P2b-2R was determined using the BIOLOG system (Bochner 1989) according to the protocol recommended by the manufacturer (BIOLOG, Hayward, California, USA). A frozen P2b-2R culture was thawed and subcultured, and a single colony was used to inoculate sterile tryptic soy broth. After $24 \mathrm{~h}$, bacteria were harvested by centrifugation (5000g for $10 \mathrm{~min}$ ), washed with $0.1 \mathrm{~mol} / \mathrm{L}$ phosphate-buffered saline (PBS), and resuspended in the same buffer to achieve $28 \%$ transmittance at optical density (OD) 640 . Aliquots of 
P2b-2R-PBS suspension $(150 \mu \mathrm{L})$ were pipetted into each microwell of a GP2 plate, incubated at $30{ }^{\circ} \mathrm{C}$ for $24 \mathrm{~h}$, and read at OD595 using a plate reader (Spectra Max 340, Sunnyvale, California, USA). Readings above 0.1 at OD595 were considered positive, indicating strong substrate utilization, whereas readings below 0.05 were considered negative, indicating no substrate utilization. Values between 0.05 and 0.1 were considered weakly positive, indicating weak substrate utilization.

\section{Results}

All of the plates containing CMC, xylan, or pectin showed visible zones of hydrolysis around colonies after incubating for two days (Fig. 1). Paenibacillus polymyxa P2b-2R was able to use $41 \%$ of the carbon sources on BIOLOG GP2 plates (i.e., 39 of the possible 95 sources; Table 1). The bacterial strain readily metabolized arabinose, xylose, mannose, glucose, galactose, and pyruvic acid-biochemicals that constitute major components of plant cell walls. However, it was unable to use other plant cell wall-related compounds such as galacturonic acid, rhamnose, glucuronic acid, and mannan. Carbon sources from the amines/amides, amino acids, polysorbates, nucleotides, or glycerol derivative group were not metabolized by the bacterial strain under these conditions.

\section{Discussion}

Bacteria that are capable of endophytic colonization may enter roots passively via existing cracks such as emergence sites of lateral roots (James et al. 1994) or, more actively, by using hydrolytic enzymes to break down plant cell wall components and metabolize organic compounds in the apoplast (Hurek et al. 1994). The latter mode of entry has been reported for plant-microbe interactions ranging from the highly specific symbiosis between Rhizobium leguminosarum biovar trifolii and white clover (Mateos et al. 1992) to more casual associations such as those between Azoarcus sp. and grasses (Hurek et al. 1994). We examined the capability of P. polymyxa P2b-2R to hydrolyze major plant cell wall components like carboxymethylcellulose (CMC), xylan, and sodium polypectate (Fig. 1 ) and to utilize carbon substrates known to comprise typical plant cell walls using in vitro plate assays (Table 1). Of the 39 carbon substrates oxidized by P2b-2R, the "carbohydrates" group represented the largest source of utilizable carbon, i.e., 23 of the 39 substrates oxidized (59\%; Table 1). These carbon sources are found naturally in plants as freely available stored forms such as sucrose, raffinose,
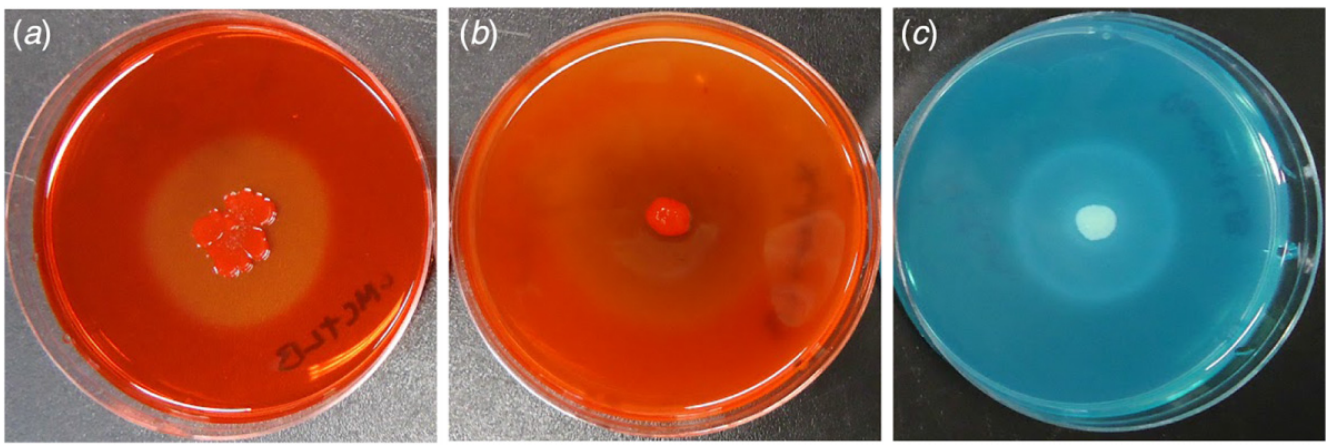

Fig. 1. Major plant cell wall components hydrolyzed by Paenibacillus polymyxa P2b-2R. Hydrolysis of (a) cellulose by P2b-2R on Luria-Bertani (LB) agar plates amended with $5 \mathrm{~g} / \mathrm{L}$ sodium carboxymethylcellulose, followed by flooding with $0.5 \%(w / v)$ Congo red; $(b)$ xylan by P2b-2R on LB agar plates amended with $5 \mathrm{~g} / \mathrm{L}$ beechwood xylan, followed by flooding with $0.5 \%(w / v)$ Congo red; and $(c)$ pectin by P2b-2R on LB agar plates amended with $5 \mathrm{~g} / \mathrm{L}$ sodium polypectate, followed by flooding with $10 \%(w / v)$ copper acetate. 
Table 1. Carbon substrate utilization profile of Paenibacillus polymyxa P2b-2R as indicated on BIOLOG plates for Gram-positive microorganisms $(n=5)$.

\begin{tabular}{|c|c|c|c|}
\hline \multirow[b]{2}{*}{ Substrate group } & \multicolumn{3}{|c|}{ Test reaction $^{a}$} \\
\hline & Positive & Weakly positive & Negative \\
\hline \multicolumn{4}{|l|}{ Carbohydrates } \\
\hline & L-Arabinose & Palatinose & D-Tagatose \\
\hline & $\alpha$-D-Lactose & Turanose & L-Rhamnose \\
\hline & Lactulose & D-Melezitose & Mannan \\
\hline & D-Trehalose & - & Gentiobiose \\
\hline & Maltose & - & Sedoheptulosan \\
\hline & D-Cellobiose & - & N-Acetyl-D-glucosamine \\
\hline & Maltotriose & - & N-Acetyl-D-mannosamine \\
\hline & D-Psicose & - & m-Inositol \\
\hline & D-Fructose & - & $\alpha$-Cyclodextrin \\
\hline & D-Raffinose & - & Glycogen \\
\hline & D-Xylose & - & - \\
\hline & D-Mannose & - & - \\
\hline & D-Galactose & - & - \\
\hline & D-Ribose & - & - \\
\hline & D-Melibiose & - & - \\
\hline & $\alpha$-D-Glucose & - & - \\
\hline & Stachyose & - & - \\
\hline & Sucrose & - & - \\
\hline & $\beta$-Cyclodextrin & - & - \\
\hline & Dextrin & - & - \\
\hline \multicolumn{4}{|c|}{ Carbohydrate derivatives } \\
\hline & $\beta$-Methyl-D-glucoside & D-Mannitol & L-Fucose \\
\hline & Arbutin & 3-Methyl glucose & $\alpha$-Methyl-D-glucoside \\
\hline & Salicin & - & $\alpha$-Methyl-D-mannoside \\
\hline & $\alpha$-Methyl-D-galactoside & - & Inulin \\
\hline & $\beta$-Methyl-D-galactoside & - & Amygdalin \\
\hline & - & - & D-Arabitol \\
\hline & - & - & Xylitol \\
\hline & - & - & D-Sorbitol \\
\hline & - & - & D-Fructose-6-phosphate \\
\hline & - & - & $\alpha$-Glucose-1-phosphate \\
\hline & - & - & D-Glucose-6-phosphate \\
\hline
\end{tabular}

(continued) 
Table 1. (continued)

\begin{tabular}{|c|c|c|c|}
\hline \multirow[b]{2}{*}{ Substrate group } & \multicolumn{3}{|c|}{ Test reaction $^{a}$} \\
\hline & Positive & Weakly positive & Negative \\
\hline \multicolumn{4}{|l|}{ Carboxylic acids } \\
\hline & $\begin{array}{l}\text { Pyruvic acid } \\
\text { methyl ester }\end{array}$ & L-Malic acid & L-Lactic acid \\
\hline & Pyruvic acid & $\begin{array}{l}\text { Succinic acid } \\
\text { mono-methyl ester }\end{array}$ & D-Malic acid \\
\hline & - & - & Acetic acid \\
\hline & - & - & $\alpha$-Hydroxybutyric acid \\
\hline & - & - & D-Galacturonic acid \\
\hline & - & - & $\beta$-Hydroxybutyric acid \\
\hline & - & - & Propionic acid \\
\hline & - & - & $\gamma$-Hydroxybutyric acid \\
\hline & - & - & D-Gluconic acid \\
\hline & - & - & p-Hydroxyphenylacetic acid \\
\hline & - & - & $\alpha$-Ketoglutaric acid \\
\hline & - & - & Succinic acid \\
\hline & - & - & $\alpha$-Ketovaleric acid \\
\hline & - & - & N-Acetyl-L-glutamic acid \\
\hline & - & - & D-Lactic acid methyl ester \\
\hline \multicolumn{4}{|l|}{ Amines/amides } \\
\hline & - & - & Lactamide \\
\hline & - & - & L-Alaninamide \\
\hline & - & - & Succinamic acid \\
\hline & - & - & Putrescine \\
\hline \multicolumn{4}{|l|}{ Amino acids } \\
\hline & - & - & D-Alanine \\
\hline & - & - & L-Alanine \\
\hline & - & - & L-Alanyl-glycine \\
\hline & - & - & L-Asparagine \\
\hline & - & - & L-Glutamic acid \\
\hline & - & - & Glycyl-L-glutamic acid \\
\hline & - & - & L-Pyroglutamic acid \\
\hline & - & - & L-Serine \\
\hline \multicolumn{4}{|l|}{ Polysorbates } \\
\hline & - & - & Tween 40 \\
\hline & - & - & Tween 80 \\
\hline
\end{tabular}


Table 1. (concluded)

\begin{tabular}{|c|c|c|c|}
\hline \multirow[b]{2}{*}{ Substrate group } & \multicolumn{3}{|c|}{ Test reaction ${ }^{a}$} \\
\hline & Positive & Weakly positive & Negative \\
\hline \multicolumn{4}{|l|}{ Nucleosides } \\
\hline & Thymidine & Inosine & Adenosine \\
\hline & - & Uridine & $2^{\prime}$-Deoxyadenosine \\
\hline \multicolumn{4}{|l|}{ Nucleotides } \\
\hline & - & - & Adenosine-5'-monophosphate \\
\hline & - & - & Thymidine- $5^{\prime}$-monophosphate \\
\hline & - & - & Uridine- $5^{\prime}$-monophosphate \\
\hline \multicolumn{4}{|l|}{ Alcohols } \\
\hline & 2,3-Butanediol & - & - \\
\hline & Glycerol & - & - \\
\hline Glycerol derivative & - & - & D-L- $\alpha$-Glycerol phosphate \\
\hline
\end{tabular}

${ }^{a}$ OD595 $>0.1=$ positive; OD595 $<0.05=$ negative; OD595 between 0.05 and $0.1=$ weakly positive.

and maltose, whereas sugars including arabinose, xylose, mannose, glucose, and galactose exist in association with major components of plant cell walls. Conclusions regarding the relationship between in vitro substrate utilization and the ability to colonize internal tissues of plants cannot be made with certainty; however, our data suggest that P2b-2R could theoretically utilize the aforementioned sugars as well as organic acids such as pyruvic acid for energy generation during endophytic colonization.

It is also interesting to note that $\mathrm{P} 2 \mathrm{~b}-2 \mathrm{R}$ was able to hydrolyze sodium polypectate (Fig. 1), the main component of pectin, but was unable to metabolize its main hydrolysis product, D-galacturonic acid. The bacterial strain was unable to use other pectin-related carbon sources as well, including rhamnose and D-glucuronic acid. It is possible that the partial degradation of pectin, known to generate oligogalacturonides (Nothnagel et al. 1983; Aziz et al. 2004), might have triggered a plant innate immune response (Galletti et al. 2009) that eventually limited the endophytic population size of P2b-2R. Alternatively, pectinolytic enzymes may provide enough destabilization of plant cell walls to allow endophytic colonization. By degrading part of the middle lamella, P2b-2R may have better access to organic compounds associated with cellulose and hemicellulose. However, the defense signal pathways in lodgepole pine, as well as the actual products of partial pectin degradation by $\mathrm{P} 2 \mathrm{~b}-2 \mathrm{R}$, need to be identified to evaluate these possibilities.

As the rhizosphere and plant interior represent two vastly different environments (Gottel et al. 2011), it is tempting to speculate that bacteria adapted to different habitats will exhibit distinctly different metabolic profiles. The link between the metabolism of specific carbon substrates and the ability of rhizosphere bacteria to colonize the interior of lodgepole pine seedlings has been reported previously using two strains of Bacillus polymyxa, L6-16R and $\mathrm{Pw}-2 \mathrm{R}$ (Shishido et al. 1995). Strain Pw-2R is a root endophyte of lodgepole pine (Shishido et al. 1995) and is capable of metabolizing sorbitol and D-melezitose, a carbohydrate commonly found in conifer sap (Lehninger 1975). As both $P$. polymyxa $\mathrm{P} 2 \mathrm{~b}-2 \mathrm{R}$ and B. polymyxa $\mathrm{Pw}-2 \mathrm{R}$ are lodgepole pine endophytes, we expected that they would have similar carbon source utilization capabilities, reflecting 
their adaptation to colonizing internal tissues of lodgepole pine. However, we found that the use of only eight carbon substrates was common between $\mathrm{Pw}-2 \mathrm{R}$ and $\mathrm{P} 2 \mathrm{~b}-2 \mathrm{R}$ when their carbon substrate utilization profiles were compared (Table 2). In addition, D-melezitose and sorbitol, which were readily used by other lodgepole pine endophytes (Shishido et al. 1995, 1999), were not metabolized by $\mathrm{P} 2 \mathrm{~b}-2 \mathrm{R}$. In light of the diversity of available nutrients produced by plants, this small overlap in carbon substrate utilization profiles of $\mathrm{P} 2 \mathrm{~b}-2 \mathrm{R}$ and $\mathrm{Pw}-2 \mathrm{R}$ suggests that these two presumably closely related endophytic strains might occupy two distinct nutritional niches of internal tissues of lodgepole pine.

Table 2. Comparison of carbon substrate utilization profiles of Bacillus polymyxa $\mathrm{Pw}-2 \mathrm{R}$ and Paenibacillus polymyxa $\mathrm{P} 2 \mathrm{~b}-2 \mathrm{R}$.

\begin{tabular}{|c|c|c|}
\hline \multirow[b]{2}{*}{ Carbon substrate } & \multicolumn{2}{|c|}{ BIOLOG test reaction } \\
\hline & $\mathbf{P w}-2 \mathbf{R}^{a}$ & P2b-2R \\
\hline$\beta$-Cyclodextrin & \pm & \pm \\
\hline Mannan & \pm & - \\
\hline Amygdalin & + & - \\
\hline L-Fucose & \pm & - \\
\hline D-Galacturonic acid & + & - \\
\hline Lactulose & \pm & + \\
\hline D-Melezitose & + & \pm \\
\hline$\alpha$-Methyl-D-galactoside & + & + \\
\hline 3-Methylglucose & + & \pm \\
\hline Palatinose & + & \pm \\
\hline D-Psicose & + & + \\
\hline D-Ribose & \pm & + \\
\hline D-Sorbitol & + & - \\
\hline D-Tagatose & + & - \\
\hline Turanose & + & \pm \\
\hline Acetic acid & \pm & - \\
\hline$\alpha$-Ketovaleric acid & + & - \\
\hline D-Lactic acid methyl ester & \pm & - \\
\hline L-Lactic acid & \pm & - \\
\hline L-Malic acid & - & - \\
\hline Methyl pyruvate & + & + \\
\hline Propionic acid & \pm & - \\
\hline Pyruvic acid & + & + \\
\hline Succinic acid & \pm & - \\
\hline L-Asparagine & \pm & - \\
\hline 2,3-Butanediol & \pm & + \\
\hline
\end{tabular}

(continued) 
Table 2. (concluded)

\begin{tabular}{lcc} 
& \multicolumn{2}{c}{ BIOLOG test reaction } \\
\cline { 2 - 3 } Carbon substrate & Pw-2 $\mathbf{R}^{a}$ & P2b-2R \\
Glycerol & + & + \\
Adenosine & + & - \\
\hline $2^{\prime}$-Deoxyadenosine & \pm & - \\
Inosine & - & \pm \\
\hline Thymidine & \pm & + \\
\hline Uridine & \pm & \pm \\
\hline D-Fructose-6-phosphate & + & - \\
$\alpha$-Glucose-1-phosphate & \pm & - \\
\hline D-Glucose-6-phosphate & + & - \\
\hline
\end{tabular}

Note: “+” positive; “ \pm ” weakly positive; “-” negative.

${ }^{a}$ Adapted from Shishido et al. (1995).

To summarize, we found that $\mathrm{P} 2 \mathrm{~b}-2 \mathrm{R}$ was able to degrade cellulose, xylan, and sodium polypectate (Fig. 1), the main constituents of plant cell walls (Compant et al. 2005; Reinhold-Hurek et al. 2006), which suggests that hydrolytic enzymes are important facilitators of endophytic colonization. However, it is difficult to interpret in vitro substrate hydrolysis without evidence of in situ enzyme activities as plate assays only demonstrate the potential enzyme activities a microbe possesses, which may or may not be expressed in nature. Future experiments involving microscopy and the use of bacterial mutants that lack cellulolytic or pectinolytic enzymes are required to ascertain the importance of in vitro enzyme activities in endophytic colonization by P. polymyxa $\mathrm{P} 2 \mathrm{~b}-2 \mathrm{R}$, a microbe which consistently formed endophytic colonies when inoculated in lodgepole pine (Anand et al. 2013; Yang et al. 2016), western red cedar (Anand and Chanway 2013b), corn (Puri et al. 2015, 2016b), canola (Padda et al. 2016b; Puri et al. 2016a), and tomato (Padda et al. 2016a).

\section{Acknowledgements}

This work was supported by funding from the Natural Sciences and Engineering Research Council of Canada (NSERC) Discovery Grant (RGPIN 41832-13) to Dr. Chris P. Chanway.

\section{Author contributions}

Conceived and designed the study: HY, CPC. Performed the experiments/collected the data: HY. Analyzed and interpreted the data: HY, AP, KPP. Contributed resources: HY, AP, KPP. Drafted or revised the manuscript: AP, KPP, CPC.

\section{Competing interests}

The authors have declared that no competing interests exist.

\section{Data accessibility statement}

All relevant data are within the paper. 


\section{References}

Adriano-Anaya M, Salvador-Figueroa M, Ocampo JA, and Garcia-Romera I. 2005. Plant cell-wall degrading hydrolytic enzymes of Gluconacetobacter diazotrophicus. Symbiosis, 40(3): $151-156$.

Anand R, and Chanway C. 2013a. Detection of GFP-labelled Paenibacillus polymyxa in autofluorescing pine seedling tissues. Biology and Fertility of Soils, 49(1): 111-118. doi:10.1007/ s00374-012-0727-9.

Anand R, and Chanway C. $2013 b . \mathrm{N}_{2}$-fixation and growth promotion in cedar colonized by an endophytic strain of Paenibacillus polymyxa. Biology and Fertility of Soils, 49(2): 235-239. doi:10.1007/ s00374-012-0735-9.

Anand R, Grayston S, and Chanway C. 2013. $\mathrm{N}_{2}$-fixation and seedling growth promotion of lodgepole pine by endophytic Paenibacillus polymyxa. Microbial Ecology, 66(2): 369-374. PMID:23420205. doi:10.1007/s00248-013-0196-1.

Azevedo JL, Maccheroni W Jr, Pereira JO, and Araújo WL. 2000. Endophytic microorganisms: a review on insect control and recent advances on tropical plants. Electronic Journal of Biotechnology, 3(1): 40-65. doi:10.2225/vol3-issue1-fulltext-4.

Aziz A, Heyraud A, and Lambert B. 2004. Oligogalacturonide signal transduction, induction of defense-related responses and protection of grapevine against Botrytis cinerea. Planta, 218(5): 767-774. PMID:14618326. doi:10.1007/s00425-003-1153-x.

Bal A, Anand R, Berge O, and Chanway CP. 2012. Isolation and identification of diazotrophic bacteria from internal tissues of Pinus contorta and Thuja plicata. Canadian Journal of Forest Research, 42(4): 807-813. doi:10.1139/x2012-023.

Bochner BR. 1989. Sleuthing out bacterial identities. Nature, 339(6220): 157-158. PMID:2654644. doi:10.1038/339157a0.

Boddey RM, Urquiaga S, Reis V, and Döbereiner J. 1991. Biological nitrogen fixation associated with sugar cane. In Nitrogen fixation. Edited by M Polsinelli, R Materassi, and M Vincenzini. Springer, the Netherlands. pp. 105-111. doi:10.1007/978-94-011-3486-6_22.

Bulgarelli D, Schlaeppi K, Spaepen S, van Themaat EVL, and Schulze-Lefert P. 2013. Structure and functions of the bacterial microbiota of plants. Annual Review of Plant Biology, 64: 807-838. PMID:23373698. doi:10.1146/annurev-arplant-050312-120106.

Cho KM, Hong SY, Lee SM, Kim YH, Kahng GG, Lim YP, et al. 2007. Endophytic bacterial communities in ginseng and their antifungal activity against pathogens. Microbial Ecology, 54(2): 341-351. PMID:17492474. doi:10.1007/s00248-007-9208-3.

Compant S, Reiter B, Sessitsch A, Nowak J, Clément C, and Ait Barka E. 2005. Endophytic colonization of Vitis vinifera L. by plant growth-promoting bacterium Burkholderia sp. strain PsJN. Applied and Environmental Microbiology, 71(4): 1685-1693. PMID:15811990. doi:10.1128/ AEM.71.4.1685-1693.2005.

Döbereiner J, Reis V, and Lazarine AC. 1988. A new $\mathrm{N}_{2}$-fixing bacteria in association with cereals and sugar cane. In Nitrogen fixation: hundred years after. Edited by H Bothe, FJ de Bruijn, and WE Newton. Gustav Fischer, Stuttgart, Germany. pp. 717-722. 
Dong Z, Canny MJ, McCully ME, Roboredo MR, Cabadilla CF, Ortega E, et al. 1994. A nitrogen-fixing endophyte of sugarcane stems (a new role for the apoplast). Plant Physiology, 105(4): 1139-1147. PMID:12232271.

Fouts DE, Tyler HL, de Boy RT, Daugherty S, Ren Q, Badger JH, et al. 2008. Complete genome sequence of the $\mathrm{N}_{2}$-fixing broad host range endophyte Klebsiella pneumoniae 342 and virulence predictions verified in mice. PLoS Genetics, 4(7): e1000141. PMID:18654632. doi:10.1371/journal. pgen.1000141.

Galletti R, de Lorenzo G, and Ferrari S. 2009. Host-derived signals activate plant innate immunity. Plant Signaling and Behavior, 4(1): 33-34. PMID:19704701. doi:10.4161/psb.4.1.7224.

Gottel NR, Castro HF, Kerley M, Yang Z, Pelletier DA, Podar M, et al. 2011. Distinct microbial communities within the endosphere and rhizosphere of Populus deltoides roots across contrasting soil types. Applied and Environmental Microbiology, 77(17): 5934-5944. PMID:21764952. doi:10.1128/ AEM.05255-11.

Hallmann J, Quadt-Hallmann A, Mahaffee WF, and Kloepper JW. 1997. Bacterial endophytes in agricultural crops. Canadian Journal of Microbiology, 43(10): 895-914. doi:10.1139/m97-131.

Hurek T, Reinhold-Hurek B, van Montagu M, and Kellenberg E. 1994. Root colonization and systemic spreading of Azoarcus sp. strain BH72 in grasses. Journal of Bacteriology, 176(7): 1913-1923. PMID:8144457.

James EK, Reis VM, Olivares FL, Baldani JI, and Döbereiner J. 1994. Infection of sugar cane by the nitrogen-fixing bacterium Acetobacter diazotrophicus. Journal of Experimental Botany, 45(6): 757-766. doi:10.1093/jxb/45.6.757.

Kavino M, Harish S, Kumar N, Saravanakumar D, Damodaran T, Sooianathasundaram K, et al. 2007. Rhizosphere and endophytic bacteria for induction of systemic resistance of banana plantlets against bunchy top virus. Soil Biology and Biochemistry, 39(5): 1087-1098. doi:10.1016/j. soilbio.2006.11.020.

Lehninger AL. 1975. Biochemistry: the molecular basis of cell structure and function. Worth Publishers, New York, New York, USA.

Mateos PF, Jimenez-Zurdo JI, Chen J, Squartini AS, Haack SK, Martinez-Molina E, et al. 1992. Cell-associated pectinolytic and cellulolytic enzymes in Rhizobium leguminosarum biovar trifolii. Applied and Environmental Microbiology, 58(6): 1816-1822. PMID:1622257.

Muñoz-Rojas J, and Caballero-Mellado J. 2003. Population dynamics of Gluconacetobacter diazotrophicus in sugarcane cultivars and its effect on plant growth. Microbial Ecology, 46(4): 454-464. PMID:14722690. doi:10.1007/s00248-003-0110-3.

Nothnagel EA, McNeil M, Albersheim P, and Dell A. 1983. Host-pathogen interactions: XXII. A galacturonic acid oligosaccharide from plant cell walls elicits phytoalexins. Plant Physiology, 71(4): 916-926. PMID:16662929. doi:10.1104/pp.71.4.916.

Padda KP, Puri A, and Chanway CP. 2016a. Effect of GFP tagging of Paenibacillus polymyxa P2b-2R on its ability to promote growth of canola and tomato seedlings. Biology and Fertility of Soils, 52(3): 377-387. doi:10.1007/s00374-015-1083-3. 
Padda KP, Puri A, and Chanway CP. 2016b. Plant growth promotion and nitrogen fixation in canola (Brassica napus) by an endophytic strain of Paenibacillus polymyxa and its GFP-tagged derivative in a long-term study. Botany, 94(12): 1209-1217. doi:10.1139/cjb-2016-0075.

Puri A, Padda KP, and Chanway CP. 2015. Can a diazotrophic endophyte originally isolated from lodgepole pine colonize an agricultural crop (corn) and promote its growth? Soil Biology and Biochemistry, 89: 210-216. doi:10.1016/j.soilbio.2015.07.012.

Puri A, Padda KP, and Chanway CP. 2016a. Evidence of nitrogen fixation and growth promotion in canola (Brassica napus L.) by an endophytic diazotroph Paenibacillus polymyxa P2b-2R. Biology and Fertility of Soils, 52(1): 119-125. doi:10.1007/s00374-015-1051-y.

Puri A, Padda KP, and Chanway CP. 2016b. Seedling growth promotion and nitrogen fixation by a bacterial endophyte Paenibacillus polymyxa P2b-2R and its GFP derivative in corn in a long-term trial. Symbiosis, 69(2): 123-129. doi:10.1007/s13199-016-0385-z.

Ravi AV, Musthafa KS, Jegathammbal G, Kathiresan K, and Pandian SK. 2007. Screening and evaluation of probiotics as a biocontrol agent against pathogenic Vibrios in marine aquaculture. Letters in Applied Microbiology, 45(2): 219-223. PMID:17651222. doi:10.1111/j.1472-765X.2007.02180.x.

Reinhold-Hurek B, Maes T, Gemmer S, van Montagu M, and Hurek T. 2006. An endoglucanase is involved in infection of rice roots by the not-cellulose-metabolizing endophyte Azoarcus sp. strain BH72. Molecular Plant-Microbe Interactions, 19(2): 181-188. PMID:16529380. doi:10.1094/ MPMI-19-0181.

Rennie RJ. 1981. A single medium for the isolation of acetylene-reducing (dinitrogen-fixing) bacteria from soils. Canadian Journal of Microbiology, 27(1): 8-14. doi:10.1139/m81-002.

Shishido M, Breuil C, and Chanway CP. 1999. Endophytic colonization of spruce by plant growthpromoting rhizobacteria. FEMS Microbiology Ecology, 29: 191-196. doi:10.1016/S0168-6496(99) 00011-2.

Shishido M, Loeb BM, and Chanway CP. 1995. External and internal root colonization of lodgepole pine seedlings by two growth-promoting Bacillus strains originated from different root microsites. Canadian Journal of Microbiology, 41(8): 707-713. doi:10.1139/m95-097.

Timmusk S, Grantcharova N, and Wagner EGH. 2005. Paenibacillus polymyxa invades plant roots and forms biofilms. Applied and Environmental Microbiology, 71(11): 7292-7300. PMID:16269771. doi:10.1128/AEM.71.11.7292-7300.2005.

Yang H, Puri A, Padda KP, and Chanway CP. 2016. Effects of Paenibacillus polymyxa inoculation and different soil nitrogen treatments on lodgepole pine seedling growth. Canadian Journal of Forest Research, 46(6): 816-821 doi:10.1139/cjfr-2015-0456. 